\title{
34. DISTRIBUTION AND CHEMISTRY OF SECONDARY MINERALS (ZEOLITES AND CLAY MINERALS) FROM HOLE 917A, SOUTHEAST GREENLAND MARGIN ${ }^{1}$
}

\author{
Alain Demant, ${ }^{2}$ Philippe Münch, ${ }^{3}$ Nathalie Romeuf, ${ }^{3}$ and Diego Morata ${ }^{4}$
}

\begin{abstract}
The Paleocene basalts recovered at Hole 917A, Leg 152, suffered very low grade metamorphism as indicated by the presence of zeolites and clay minerals. Chabazite, heulandite-group zeolites, thomsonite, analcite, and natrolite occur as vesicle fillings and in the groundmass, whereas chlorite, interlayered chlorite/smectite, and saponite/smectite were identified in the same microdomains; saponite is restricted to olivine pseudomorphs. These mineralogical assemblages indicate that the temperature of the metamorphic transformations did not exceed $170^{\circ} \mathrm{C}$. The regular increase of cationic Na toward the top of the volcanic pile indicates that the zeolites formed during a hydrothermal process in an open system clearly influenced by seawater. This metamorphism was therefore a late post-emplacement event that affected the whole volcanic pile and occurred after the opening of the North Atlantic Ocean.
\end{abstract}

\section{INTRODUCTION}

Hole 917A obtained a complete record of the seaward dipping reflector sequences (SDRS) on the southeast Greenland Margin. The rocks from this 779-m Paleocene volcanic succession are predominantly basaltic, but some acidic lavas and tuffs were also recovered. The volcanic succession was divided, based on the petrography and geochemistry, into three stratigraphic series, which are referred to as the Upper, Middle, and Lower Series. Relatively thin flows of picrites and olivine-phyric basalts constitute the Upper Series (141.5 m). The Middle Series (193.4 m) is characterized by thicker and more differentiated basalts, as well as dacitic lavas and tuffs. Finally, the Lower Series $(444 \mathrm{~m})$ shows cyclic variations in composition from picritic lavas to more differentiated aphyric basalts (Larsen, Saunders, Clift, et al., 1994). Apart from some heavily weathered and brecciated samples, lavas recovered from Hole 917A are relatively fresh and have the typical mineralogy of tholeiitic magmas (Demant, this volume).

Secondary minerals are, however, widely distributed throughout the volcanic sequence. The secondary mineralogy, dominated by zeolites and clay minerals, is characteristic of very low-grade metamorphism of volcanic rocks present in active geothermal areas or in shallow burial sequences (Coombs et al., 1959; Zen and Thompson, 1974; Liou et al., 1985). The aim of this study is to provide detailed information on the petrography and mineral chemistry of the secondary mineral parageneses and to estimate the physico-chemical conditions of very low-grade metamorphic transformations occurring within the 779-m-thick volcanic pile drilled at Hole 917A.

\section{ANALYTICAL METHODS}

Petrographic studies were conducted on 65 thin sections from which 28 were selected for secondary mineral analyses. Zeolites and clay minerals were analyzed using a Camebax electron microprobe at

'Saunders, A.D., Larsen, H.C., and Wise, S.W., Jr. (Eds.), 1998. Proc. ODP, Sci. Results, 152: College Station, TX (Ocean Drilling Program)

${ }^{2}$ Laboratoire de Pétrologie Magmatique, URA CNRS 1277 et FU 17, CEREGE BP 80, 13545 Aix-en-Provence Cedex 04, France. ADEMANT@ARBOIS.CEREGE.FR

${ }^{3}$ Centre de Sédimentologie Paléontologie, URA CNRS 1208, Université de Provence, 3 Place Victor Hugo, 13331 Marseille Cedex 3, France.

${ }^{4}$ Departamento de Mineralogía Petrología y Geoquímica, Facultad de Ciencias del Mar, Universidad de Cadiz, 11510 Puerto Real (Cadiz), Spain. the University of Montpellier II. The microprobe was operated with an accelerating voltage of $20 \mathrm{kV}$, sample current of $10 \mathrm{nA}$, and an integrated counting time ranging from 6 to $20 \mathrm{~s}$ depending on the minerals analyzed. A new accurate computer correction program (Merlet, 1994) was used to calculate the elemental concentrations, with sodium being analyzed first because of its tendency to migrate under the electron beam. A defocused beam $(5$ or $7 \mu \mathrm{m})$ was used for zeolites to prevent a rapid destruction of the mineral under electron bombardment, and analyses have been selected on the basis of their low chemical balance (Passaglia, 1970). This factor, named E\%, is defined by the formula:

$$
\mathrm{E} \%=\frac{100 \cdot[(\mathrm{Al}+\mathrm{Fe})-(\mathrm{Na}+\mathrm{K})-2 \cdot(\mathrm{Ca}+\mathrm{Mg}+\mathrm{Ba}+\mathrm{Sr})]}{[(\mathrm{Na}+\mathrm{K})+2 \cdot(\mathrm{Ca}+\mathrm{Mg}+\mathrm{Ba}+\mathrm{Sr})] .}
$$

Zeolites with E\% > 10 were rejected. In fact, more than $90 \%$ of the analyses were retained using the special operating conditions described above. An exception was zeolites from the heulandite-group, for which the percentage retained is less than 30 . In total, 250 analyses of high quality were obtained and are included, with the corresponding structural formulae, on the CD-ROM in the back pocket of this volume. Some additional analyses were performed by D. Velde on a SX-50 Cameca microprobe at the University of Paris VI, under the same analytical conditions, to check the $\mathrm{Ba}$ and $\mathrm{Sr}$ contents of certain zeolites.

\section{SECONDARY MINERAL ASSEMBLAGES}

Different secondary mineral assemblages have been recognized in the lavas of Hole 917A based on petrographic observations and shipboard X-ray diffraction (XRD) studies. Table 1 presents a summary of downhole variation of the secondary mineral parageneses and their relation to petrographic types. Secondary phases are mainly clay minerals and zeolites, whereas calcite is more occasional and appears mostly in fractures or in the center of the vesicles in the upper part of the volcanic pile and in the Lower Series. Textural observations indicate that calcite crystallized late during tilting and faulting of the volcanic sequence (Larsen, Saunders, Clift, et al., 1994). In the vesicles of the more evolved basalts from the Middle Series, opal and chalcedony fillings (Unit 44 and 47) have been determined during initial onboard studies. Tridymite, preceding clay minerals and zeolites, was identified by petrographic observation and microprobe investigation in the voids of Unit 54 dacite during shore-based studies. 
Table 1. Summary of secondary minerals identified by thin section studies and microprobe analyses in Hole 917A.

\begin{tabular}{|c|c|c|c|c|c|c|c|c|c|c|c|c|c|}
\hline \multirow{3}{*}{$\begin{array}{l}\text { Core, section, } \\
\text { interval }(\mathrm{cm})\end{array}$} & \multirow{3}{*}{$\begin{array}{l}\text { Depth } \\
\text { (mbsf) }\end{array}$} & \multirow[b]{3}{*}{ Unit } & \multirow[b]{3}{*}{ Petrographical type } & \multicolumn{10}{|c|}{ Secondary minerals } \\
\hline & & & & \multicolumn{4}{|c|}{ Phyllosilicate types } & \multicolumn{6}{|c|}{ Zeolites } \\
\hline & & & & 1 & 2 & 3 & 4 & $\mathrm{Cbz}$ & Hul & Tms & Ntr & Anl & Cal \\
\hline \multicolumn{14}{|l|}{ 152-917A- } \\
\hline Upper Series & & & & & & & & & & & & & \\
\hline $8 \mathrm{R}-4,15-20$ & $\begin{array}{l}60.20 \\
74.48\end{array}$ & 6 & Aphyric Ol basalt & & $\mathrm{X}$ & & & $\mathrm{X}(1,2)$ & & & & & \\
\hline $10 \mathrm{R}-1,58-61$ & 74.48 & 9 & Aphyric $\mathrm{Ol}$ basalt & & $\mathrm{X}$ & & & & & & & & \\
\hline $11 \mathrm{R}-2,124-128$ & 87.17 & 13 & Aphyric $\mathrm{Ol}$ basalt & & $\mathrm{X}$ & & & $\mathrm{X}(1,2)$ & & & & & \\
\hline $13 \mathrm{R}-2,70-75$ & 103.25 & 16 & Aphyric Ol basalt & $\mathrm{X}$ & $\mathrm{X}$ & & & $\mathrm{X}(1,2)$ & & & & & \\
\hline $18 \mathrm{R}-3,98-101$ & 149.56 & 25 & Picrite & $\mathrm{X}$ & $\mathrm{X}$ & & & $X(1)$ & & & & & \\
\hline 18R-6, 63-66 & 153.57 & 27 & Ol-phyric basalt & $\mathrm{X}$ & $\mathrm{X}$ & & & $X(1)$ & & & & $\mathrm{X}(1)$ & \\
\hline $20 \mathrm{R}-4,122-127$ & 169.97 & $32 \mathrm{~B}$ & Picrite & $\mathrm{X}$ & $\mathrm{X}$ & & & $X(3)$ & & & $\mathrm{X}(3)$ & & $\mathrm{X}$ \\
\hline \multicolumn{14}{|l|}{ Middle Series } \\
\hline $23 \mathrm{R}-3,6-7$ & 194.81 & $35 \mathrm{~B}$ & Tuff & & & & & & $X(2,3)$ & & & & \\
\hline $27 \mathrm{R}-1,2-3$ & 215.32 & 39 & Aphyric basalt & & & $\mathrm{X}$ & $\mathrm{x}$ & & & & & & \\
\hline $40 \mathrm{R}-4,78-81$ & 302.48 & 52 & Aphyric basalt & & & $\mathrm{X}$ & & & & & & & \\
\hline $45 \mathrm{R}-1,55-59$ & 326.85 & 53 & Aphyric basalt & & & $\mathrm{X}$ & & & $\mathrm{X}(2,3)$ & & & & \\
\hline $47 \mathrm{R}-2,38-42$ & 347.54 & 54 & Dacite & & & $\mathrm{x}$ & & & $\mathrm{X}(2)$ & & & & \\
\hline \multirow{2}{*}{\multicolumn{14}{|c|}{ Lower Series }} \\
\hline & & & & & & & & & & & & & \\
\hline 57R-3, 64-67 & 416.33 & $61 \mathrm{~B}$ & Picrite & $\mathrm{X}$ & $\mathrm{X}$ & & & & & & & & $\mathrm{X}$ \\
\hline $65 \mathrm{R}-3,127-130$ & 484.40 & 69 & Aphyric Ol basalt & & & $\mathrm{X}$ & & & $\mathrm{X}(2)$ & & & & \\
\hline 67R-3, 130-132 & 503.73 & 70 & Ol PI Cpx-phyric basalt & & & $\mathrm{x}$ & & & & & & & \\
\hline $72 \mathrm{R}-1,82-85$ & 548.12 & $73 \mathrm{~A}$ & Ol-phyric basalt & $\mathrm{X}$ & $\mathrm{X}$ & & & $\mathrm{X}(1,3)$ & & $\mathrm{X}(1,3)$ & & & \\
\hline $78 \mathrm{R}-3,93-95$ & 598.98 & 76 & Aphyric Ol basalt & & $\mathrm{X}$ & & & $\mathrm{X}(1,3)$ & & & & & \\
\hline $79 \mathrm{R}-2,64-67$ & 607.08 & 78 & Ol-phyric basalt & & $\mathrm{X}$ & & & & & & & & \\
\hline $80 \mathrm{R}-4,40-44$ & 619.29 & 79 & Aphyric Ol basalt & & $\mathrm{X}$ & & & $\mathrm{X}(1,2)$ & & & & & \\
\hline $87 \mathrm{R}-5,42-46$ & 687.15 & 84 & Aphyric Ol basalt & & $\mathrm{X}$ & & & $X(1,3)$ & & $X(1,2)$ & & $\mathrm{X}(2)$ & \\
\hline 88R-7, 83-86 & 700.52 & 84 & Aphyric Ol basalt & & $\mathrm{X}$ & & & $\mathrm{X}(1)$ & & $\mathrm{X}(1)$ & & & \\
\hline 90R-1, 58-59 & 710.68 & 85 & Ol Pl-phyric basalt & $\mathrm{X}$ & $\mathrm{X}$ & & & $X(1)$ & & & & $\mathrm{X}(2)$ & \\
\hline 90R-6, 104-107 & 717.33 & 86 & Ol Pl-phyric basalt & & $\mathrm{X}$ & & & $X(1,2,3)$ & & $\mathrm{X}(2)$ & & & \\
\hline 94R-1, 71-74 & 740.81 & 87 & Aphyric Ol basalt & & $\mathrm{X}$ & & & & & & & & \\
\hline $94 \mathrm{R}-3,64-65$ & 743.31 & 87 & Aphyric Ol basalt & & $\mathrm{X}$ & & & & & & & & \\
\hline 97R-2, 10-11 & 770.35 & 89 & Aphyric Ol basalt & & & & & $\mathrm{X}(1,2)$ & & & & $\mathrm{X}(1)$ & $\mathrm{X}$ \\
\hline 9R-2, 57-60 & 790.34 & 90 & Aphyric Ol basalt & & $\mathrm{X}$ & & & $\mathrm{X}(1,2)$ & & & & & $\mathrm{X}$ \\
\hline
\end{tabular}

Notes: Type 1 phyllosilicate $=$ mica-like; type $2=$ green clays; type $3=$ brown clays; type $4=$ grass-green clays. Abbreviations for zeolites are: Cbz $=$ chabazite; Hul $=$ heulanditeclinoptilolite; $\mathrm{Tms}=$ thomsonite; $\mathrm{Ntr}=$ natrolite; Anl = analcite; Cal = calcite. $(1)=$ zeolites present in the groundmass; $(2)=$ zeolites in the vesicles; $(3)=$ zeolites in veins. Unit 16, which was defined as an aphyric olivine basalt on board, corresponds in fact to a picrite (Demant, this volume).

Clay minerals are present in three different microdomains: (1) as the earliest filling of primary voids such as vesicles, veins, or veinlets; (2) as pseudomorphs after olivine and as an alteration product of plagioclase; and (3) in the groundmass replacing glass. Four different types of clay minerals have been distinguished on the basis of their optical features. Type 1 is colorless, has a mica-like appearance due to high birefringence colors, and occurs solely as replacement of olivine phenocrysts in the picritic and olivine-phyric lavas of the Upper and Lower Series. Type 2 clay minerals have light green to yellowish-green colors and often a blue-gray or brown birefringence typical of chlorites. A progressive change of composition is frequently observed in the voids and reflected by changes in color. Type 2 clay minerals also occur in both the Upper and Lower Series, as fibroradial assemblages lining and filling the cavities, as a replacement of olivine, or as alteration of plagioclase and groundmass. They always precede the crystallization of zeolites either in the open spaces or in the groundmass. When present in olivine, type 2 clay minerals replace early-formed type 1 mica-like clay minerals. Type 3 clay minerals have a brown to reddish-brown color and occur mainly in the Middle Series as vesicle fillings and groundmass replacement. Type 4 clay minerals have been observed only in Unit 39, an aphyric basaltic dike that cuts the Middle Series. Vesicles in this dike are filled with clay minerals having an intense grass-green color resembling that of celadonite.

A precise identification of clay minerals is generally based also on XRD studies. In this work, because the sampling was done first of all for primary mineral studies, the rocks are generally relatively fresh and clay minerals were analyzed on the same microprobed samples.

Zeolites were observed as open space fillings or as replacement of the groundmass in Hole 917A. The most common species identified in thin sections were chabazite and heulandite-group zeolites, and to a lesser extent thomsonite, analcite, and natrolite.
Chabazite occurs in the Upper and Lower Series as clear massive aggregates $(0.1-1.5 \mathrm{~mm})$ in the groundmass or with perfect rhombohedral shapes in the vesicles. The presence of orthogonal cleavages is a useful reconnaissance criteria for identification. Some crystals, in veins or vesicles, are clearly zoned. In ophitic textures, such as present in Unit 84, chabazite crystallized in irregular voids, after an initial coating by green clay minerals, enclosing plagioclase laths that are only slightly altered. The textural pattern of the interstitial secondary minerals seems to indicate that a complete dissolution of glass has occurred before the precipitation of the secondary minerals sequence.

Zeolites belonging to the heulandite-group were identified during shore-based studies; they are the only zeolites present in the Middle Series, but they have been also found in the upper part of the Lower Series (Table 1). Heulandite-group zeolites form small (0.1-0.2 mm) tabular crystals in veins or vesicles. They show a well-developed cleavage (010) and have very low birefringence. The precise identification of heulandite-group zeolites, however, is based on their thermal property (Mumpton, 1960) or chemical composition (Boles, 1972; Mason and Sand, 1960).

Natrolite is present in the Upper Series, mainly in veins, and crystallized as white, plumose or radiating crystals in association with chabazite. Thomsonite occurs only in the Lower Series, and has various morphologies, including clear needle-like crystals in the groundmass, and clear to brownish radiating fibers in the vesicles where it crystallized after analcite or chabazite. Analcite, with perfect euhedral form, was recognized visually on board in the vesicles of basalts, in the lower part of the Upper Series. In thin section, analcite occurs as clear translucent patches in the groundmass of Units 27 and 89, and is present also in some vesicles of the Lower Series. Finally, phillipsite was determined by shipboard XRD in Unit 1 but has not been found in the studied thin sections. 
DISTRIBUTION AND CHEMISTRY OF SECONDARY MINERALS

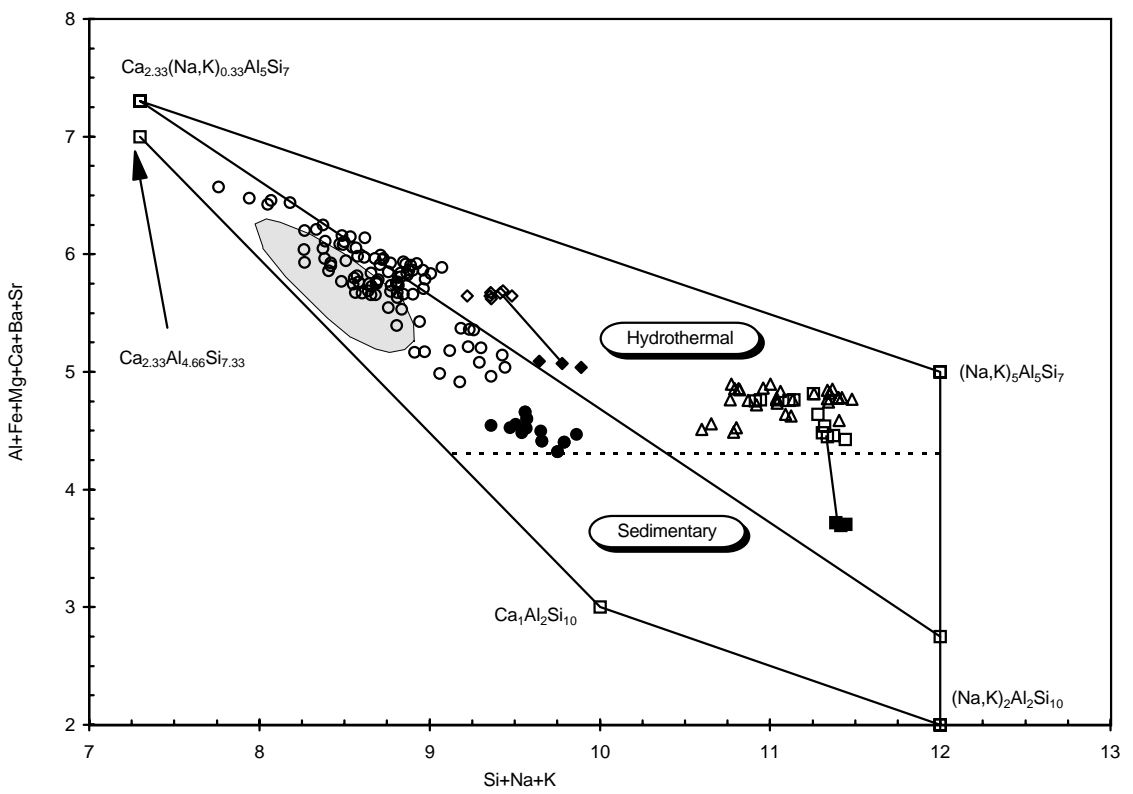

Figure 1. $\mathrm{Al}+(\mathrm{Fe}+\mathrm{Mg}+\mathrm{Ca}+\mathrm{Ba}+\mathrm{Sr})$ vs. $\mathrm{Si}+(\mathrm{Na}$ $+\mathrm{K})$ diagram of Hole 917A chabazites and genetic classification of chabazites after Sameshima (1978). Diamonds $=$ Unit $73 \mathrm{~A}$; open symbols $=$ chabazites present in the matrix; solid symbols $=$ chabazites present in veins. Open circles $=$ chabazites from the Lower Series; solid circles $=$ chabazites present in the veins of Units 76 and 84. Open triangles = chabazites from the Upper Series. Open squares $=$ chabazites present in the matrix of Unit 6; solid squares $=$ chabazites in the vesicles of Unit 6. Stippled area $=$ field of chabazites from the îles Kerguelen (Verdier et al., 1988; Nativel et al., 1994).

\section{MINERAL CHEMISTRY Zeolites}

Zeolites from Hole 917A are predominantly sodi-calcic (chabazite, thomsonite, and clinoptilolite), but pure sodic species (analcite and natrolite) are also present, mainly in the vesicles and veins.

Chabazite is the most ubiquitous species in the lavas of the Upper and Lower Series (Table 1), but it exhibits a wide compositional range as evidenced by the distribution of the analyses on the genetic classification diagram of Sameshima (1978). All the analyses plot in the field of hydrothermal chabazites (Fig. 1) with the exception of crystals present in the vesicles of Unit 6, the uppermost unit analyzed, which fall in the field of sedimentary chabazites. The compositional variations of chabazites are observed at two different scales. At a global scale, chabazites from the Upper Series have a cationic composition clearly different from that of the Lower Series chabazites, the former being sodic, whereas the latter are calco-sodic (Fig. 2). Similar calco-sodic chabazites are common in basaltic volcanic piles and were described, for example, in the Kerguelen Islands (Verdier et al., 1988; Nativel et al., 1994). At the scale of an individual lava flow, zeolites crystallizing in the vesicles are always more silica-rich and more sodic than zeolites present in the groundmass. Such a trend, as illustrated by Figures 1 and 2, indicates that the chemical evolution of the chabazites is mostly controlled by $\mathrm{Ca}(\mathrm{Al})===>\mathrm{Na}(\mathrm{Si})$ substitutions. $\mathrm{Ba}$ and $\mathrm{Sr}$ were analyzed in some chabazites from the Lower Series. Barium contents are always lower than $0.4 \mathrm{wt} \%$, whereas $\mathrm{Sr}$ contents are not insignificant and reach $1.2 \mathrm{wt} \%$ in Unit 90, $0.8 \mathrm{wt} \%$ in Unit 89 , and $0.5 \mathrm{wt} \%$ in Unit $73 \mathrm{~A}$. Such contents are, however, much less than the 5-7 wt\% SrO recorded in some strontian chabazites from the Tertiary basaltic lavas of the Plateau des Coirons, France (Robert, 1988; Robert et al., 1988). The Ba anomaly of some Lower Series basalts does not seem to be due to the abundance of zeolites.

Numerous attempts to provide a chemical classification of the heulandite-group zeolites have been undertaken (Mason and Sand, 1960; Alietti, 1972; Boles, 1972; Hawkins, 1974; Gottardi and Galli, 1985), but none of them is fully satisfactory. The most useful chemical criterion to distinguish heulandite from clinoptilolite is still the $\mathrm{Si} / \mathrm{Al}$ ratio (Boles, 1972); clinoptilolite has $\mathrm{Si} / \mathrm{Al}>4$ and heulandite $\mathrm{Si} / \mathrm{Al}<4.0$. In Hole 917A, heulandite-group zeolites have $\mathrm{Si} / \mathrm{Al}$ ratios ranging from 3.56 to 4.25 . Most of the analyzed crystals, how- ever, have $\mathrm{Si} / \mathrm{Al}<4.0$ and correspond therefore to heulandite s.s. (Fig. 3). The cationic composition is quite variable but evolves regularly from sodic to sodi-calcic composition (Fig. 2). It must be emphasized that heulandite-group zeolites, the only zeolites found in the Middle Series volcanics, have cationic compositions intermediate between those of the sodic chabazite from the Upper Series and those of the calco-sodic chabazites from the Lower Series (Fig. 2). Ba and $\mathrm{Sr}$ were also analyzed in heulandite-group zeolites from the dacite (Unit 54). Their concentrations are low $(\mathrm{BaO}<0.34 \mathrm{wt} \%$ and $\mathrm{SrO}<$ $0.1 \mathrm{wt} \%$ ) and as the modal percentage of zeolites is $5 \%$, cannot account for the high Ba content (1200 ppm, Larsen et al., 1994; Fitton et al., Chap. 28, this volume) of this lava.

Analcite crystallized principally in the vesicles in basalts from Hole 917A. It has a simple chemical composition, close to the stoichiometric formula $\mathrm{Na}_{16}\left(\mathrm{Al}_{16} \mathrm{Si}_{32} \mathrm{O}_{96}\right) 16 \mathrm{H}_{2} \mathrm{O}$. However, analcite from Unit 89, which crystallized in the groundmass, contains about 1 $\mathrm{wt} \% \mathrm{CaO}$. Natrolite is relatively rare in Hole $917 \mathrm{~A}$ and was analyzed in only one sample, in a vein cutting Unit 32B picrite. Natrolite is more alumina-rich $(\mathrm{Si} / \mathrm{Al}=1.5)$ and more sodic than analcite. As in the îles Kerguelen (Verdier et al., 1988), natrolite from Hole 917A is more hydrated than the theoretical composition and seems to correspond to paranatrolite as defined by Chao (1980). Analcite and natrolite show in fact little compositional range. This is a common characteristic of these zeolites either for those present in the Tertiary lavas from Kerguelen (Nativel et al., 1994), or those found in the Triassic basalts from Turkey (Malley et al., 1983), or the Jurassic basalts from southeast Spain (Morata et al., 1995).

Thomsonite is a calco-sodic zeolite that can be discriminated from the other fibrous species such as mesolite and scolecite by its lower $\mathrm{Si} / \mathrm{Al}$ ratio. Thomsonite is present only in the Lower Series. Its chemical variation is mainly controlled by the $\mathrm{NaSi}<=====>\mathrm{CaAl}$ coupled substitutions. The compositional range is relatively large but no regular variation is observed with depth. In Unit 86 a clear difference is observed in the vesicles: the first infillings are composed of transparent acicular crystals while the center is filled with brownish radiating needle-like crystals. The latter have higher $\mathrm{Si} / \mathrm{Al}$ ratios and tend therefore toward the mesolite pole. However, as the compositional evolution is progressive, we include this fibrous zeolite in the thomsonite group. The brownish fibrous zeolite was initially thought to be scolecite on the basis of onboard XRD determination, but generally scolecite is a more calcic species. 
Figure 2. Triangular diagram showing ratios of exchangeable cations in chabazite and heulanditegroup zeolites. Open circles $=$ Lower Series chabazites. Open diamonds = Middle Series heulanditegroup zeolites. Open triangles $=$ Upper Series chabazites.
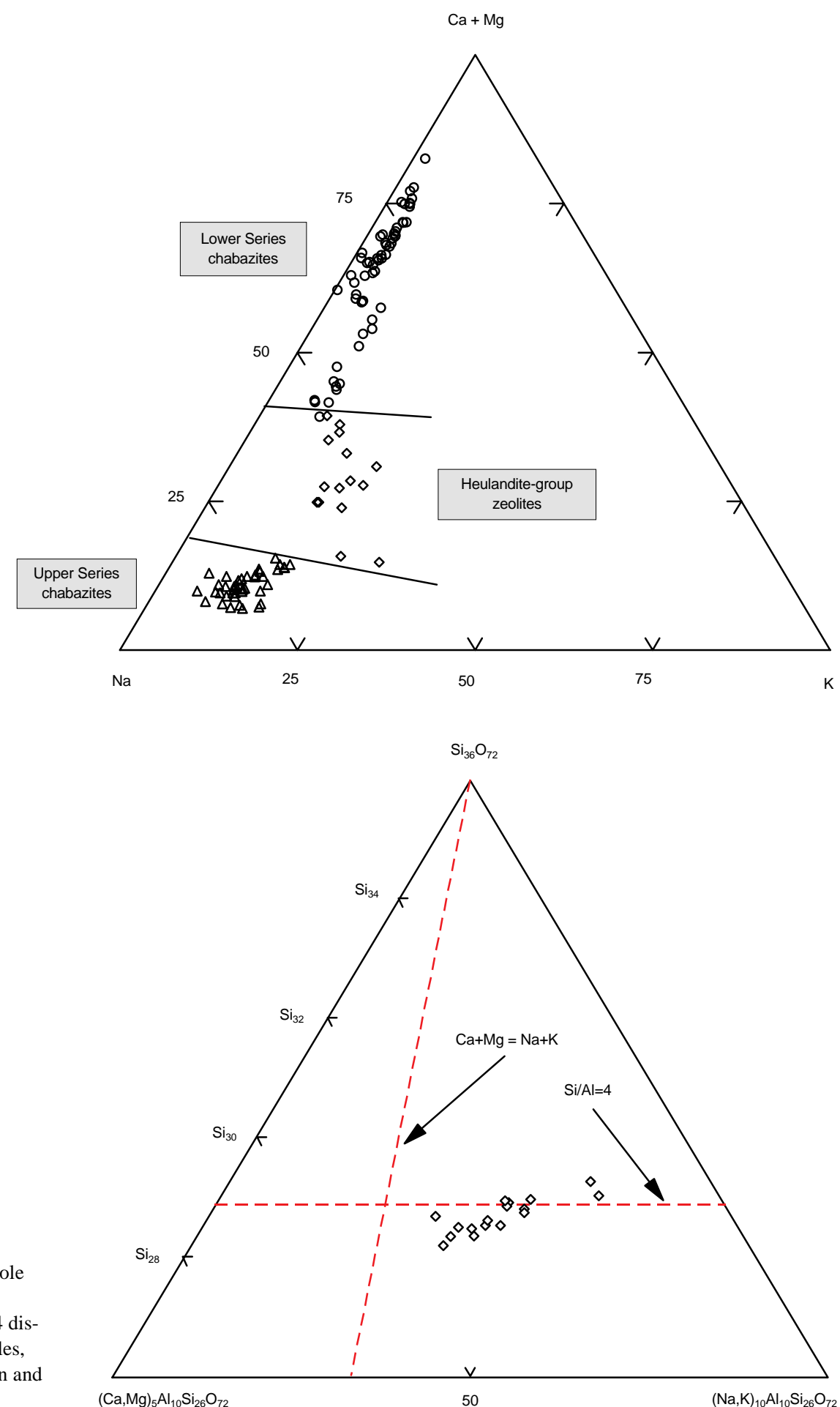

Figure 3. Mole plot of heulandite-group zeolites from Hole $917 \mathrm{~A}$ in the triangle $\mathrm{Si}_{36} \mathrm{O}_{72}-(\mathrm{Ca}, \mathrm{Mg})_{5} \mathrm{Al}_{10} \mathrm{Si}_{26} \mathrm{O}_{72}-$ $(\mathrm{Na}, \mathrm{K})_{10} \mathrm{Al}_{10} \mathrm{Si}_{26} \mathrm{O}_{72}$ (after Alietti et al., 1977). Si/Al = 4 discriminant line for clinoptilolite and heulandite (after Boles, 1972); $\mathrm{Ca}+\mathrm{Mg}=\mathrm{Na}+\mathrm{K}$ discriminant line (after Mason and Sand, 1960).

\section{Clay Minerals}

A precise identification of clay minerals requires both XRD studies and electron microprobe analyses as exemplified by several authors (Bettison and Schiffman, 1988; Bettison-Varga et al., 1991; Robinson et al., 1993).

Several chemical parameters can be used to discriminate chlorite, interstratified chlorite/smectite, and smectite, provided all the analyses have been recalculated on the basis of chlorite formula (i.e., 28 oxygen atoms). The most useful is the Xc parameter, which corresponds to the percentage of chlorite layers present in the phyllosili- cate structure (Wise's method in Bettison and Schiffman, 1988). Xc varies from 0 for smectites s.s. to 1 for pure chlorites (Schiffman and Fridleifsson, 1991). Moreover, the sum of the non-interlayer cations $\left(\mathrm{Si}+\mathrm{Al}_{\mathrm{tot}}+\mathrm{Fe}_{\mathrm{tot}}+\mathrm{Mg}+\mathrm{Mn}\right)$ varies from 20 for the chlorite endmember to 17.82 for the smectite end-member, and the sum of interlayer cations $(\mathrm{Ca}+\mathrm{Na}+\mathrm{K})$ is greater than 0.1 for phyllosilicates that include smectite interlayers in their structure (Schiffman and Fridleifsson, 1991). Finally, Bettison and Schiffman (1988) have demonstrated that phyllosilicates containing more than $6.25 \mathrm{Si}$ cations per formula unit include smectite interlayers in their structure. These different poles are classically represented on a non-interlayer 
cations $\left(\mathrm{Si}+\mathrm{Al}_{\text {tot }}+\mathrm{Fe}_{\text {tot }}+\mathrm{Mg}+\mathrm{Mn}\right)$ vs. total $\mathrm{Al}$ diagram. In this diagram the position of the clinochlore (chlorite s.s.), saponite (trioctaedral smectite), beidellite (di-octaedral smectite), and celadonite poles were defined by Schiffman and Fridleifsson (1991), and slightly modified by Robinson et al. (1993). All the phyllosilicates analyzed in the lavas of Hole 917A are presented on this diagram (Fig. 4A). Most of the analyses plot in a field comprised between the chloritic and smectitic end-members. The same analyses are also plotted on the interlayer cations $(\mathrm{Na}+\mathrm{K}+\mathrm{Ca})$ vs. Si diagram (Fig. 4B).

However, although this study is based on microprobe data only, the differences in chemistry correlate well with the petrographical types defined from thin section studies. The mica-like clay minerals (type 1) plot near the pole of pure saponite (solid symbols, Fig. 4A); the green to yellowish-green phyllosilicates (type 2) correspond to interstratified chlorite/smectites with variable amount of chlorite layers; the brown to reddish-brown clay minerals present in the Middle Series (type 3) correspond to mixed layer celadonite/smectites with a near saponitic composition, and the intense grass-green phyllosilicates (type 4) correspond also to mixed-layer saponite/ celadonite but with a higher celadonite component (Unit 39; Fig. 4A).

The distinction between the mica-like saponites replacing olivine and the interstratified chlorite/smectites is also expressed on the $(\mathrm{Ca}$ $+\mathrm{Na}+\mathrm{K}$ ) vs. Si diagram (Fig. 4B) by a high Si content per formula unit $(\mathrm{Si}>9.0)$ with a rather low interlayer charge for the former and a low $\mathrm{Si}$ content $(6.6<\mathrm{Si}<8.3)$ and a variable interlayer charge (up to 1.85) for the latter. The mixed layer saponite/celadonite from the Middle Series, and from Unit 69 of the Lower Series, are characterized by a high Si content (around 10) and an interlayer charge up to 2.0 (Fig. 4B). In the Upper and Lower Series, at the scale of the thin section, slight differences are observed in the phyllosilicate compositions depending on the microdomain in which they occur. Saponite s.s., corresponding to mica-like minerals, occurs only as pseudomorphs after olivine phenocrysts in the olivine-rich rocks. This indicates a strong control of the host mineral on the chemistry of the new-
A

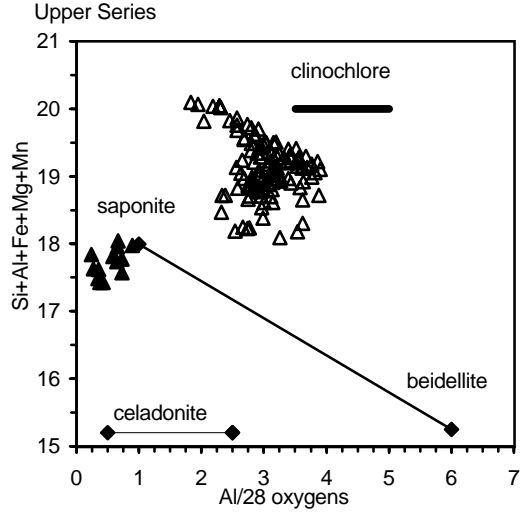

Middle Series

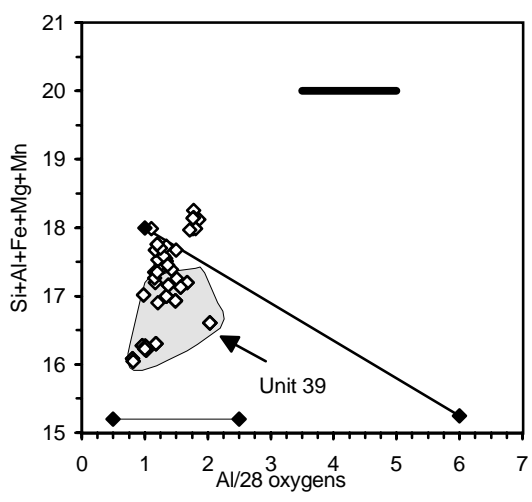

Lower Series

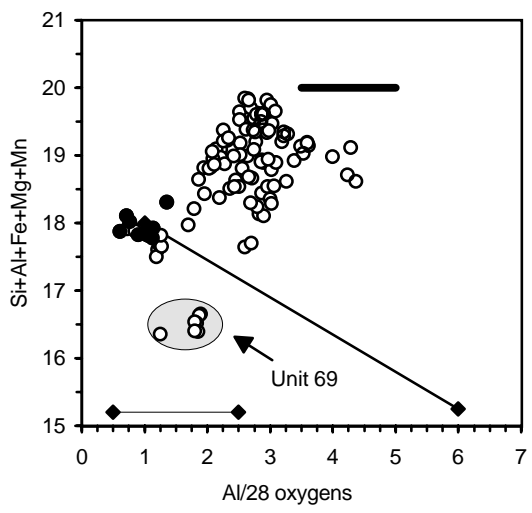

B
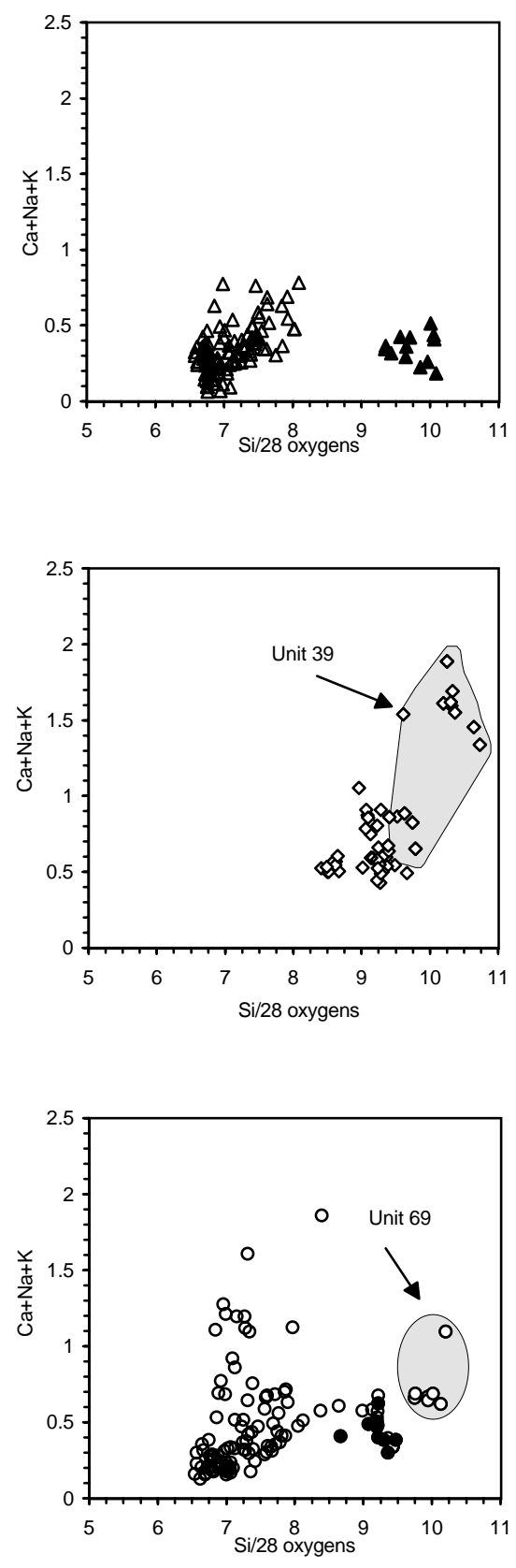

Figure 4. A. Noninterlayer $(\mathrm{Si}+\mathrm{Al}+\mathrm{Fe}+\mathrm{Mg}+\mathrm{Mn})$ cation total vs. $\mathrm{Al}_{\text {tot }}$ for clay minerals from the Upper, Middle, and Lower Series. End-member compositions (solid diamonds) are taken from Robinson et al.

(1993). B. Interlayer $(\mathrm{Ca}+\mathrm{Na}+\mathrm{K})$ cation total vs. Si. Solid symbols correspond to mica-like phyllosilicates replacing olivine in picrites and olivine-phyric basalts. 
ly formed $\mathrm{Mg}$-rich phyllosilicates during this early stage of alteration of the olivine. Textural relationships show that the formation of chloritic clay minerals around olivine phenocrysts, in the groundmass, and as a partial replacement of plagioclase occurs later and therefore corresponds to a second stage of alteration. The most striking feature revealed by the clay mineralogy is the clear difference in chemistry of clay mineral assemblages in the different series. In the Upper and Lower Series (except for Unit 69 from the Lower Series where clay minerals are identical to those from the Middle Series), clay minerals correspond to interstratified chlorite/saponite, and saponite s.s., whereas, in the Middle Series, phyllosilicates are mainly represented by saponite s.s. and mixed-layer saponite/celadonite (Fig. 4). The interstratified chlorite/smectites and chlorites are slightly less ferriferous and more magnesian in the Upper Series than in the Lower Series, but their $\mathrm{Fe} / \mathrm{Mg}$ ratio does not appear to vary within a single series (Fig. 5). Finally, it must be emphasized that some analyses of clay minerals have not been plotted due to their high Ca content (e.g., $\mathrm{CaO}>2 \mathrm{wt} \%$ in Unit 84); this can be attributed to a very fine intermixing of calcite and phyllosilicates as seen in Leg 104 (LeHuray and Johnson, 1989).

\section{ESTIMATION OF PHYSICO-CHEMICAL CONDITIONS OF METAMORPHISM}

\section{Temperature and Pressure}

The secondary mineral assemblages recognized in Hole 917A basalts are in accordance with very low-grade metamorphism in the low-temperature zeolite facies. Similar low-grade basaltic metavolcanics have been described in various geological settings, including ocean-floor metamorphism (e.g., Evarts and Schiffman, 1983), hydrothermal metamorphism in geothermal systems (e.g., Kristmannsdóttir and Tómasson, 1978), diastathermal metamorphism (Robinson, 1987; Robinson and Bevins, 1989), and burial metamorphism (e.g., Aguirre and Offler, 1985; Schmidt, 1993). Based on these examples, experimentally calibrated equilibria for zeolites (Liou, 1971; Liou et al., 1991) and the petrogenetic grids defined for very lowgrade metabasalts (Liou et al., 1987; Frey et al., 1991), the temperatures of formation of the observed zeolite assemblages can be roughly estimated. Analcite and thomsonite indicate slightly higher temperatures than chabazite. The transition to the high-temperature zeolite facies, characterized by the appearance of laumontite, was estimated at about $120^{\circ}-150^{\circ} \mathrm{C}$ (Liou, 1971), or in the range $155^{\circ}-180^{\circ} \mathrm{C}$ (Cho et al., 1987).

The phyllosilicates can also be used for temperature estimations. A chlorite geothermometer has been established (Cathelineau and Nieva, 1985; Cathelineau, 1988) based on a linear regression between tetrahedral $\mathrm{Al}\left(\mathrm{Al}^{\mathrm{IV}}\right)$ content of the phyllosilicates and in situ measured temperatures in a Mexican geothermal drill hole (Los Azufres). Several studies (Bevins et al., 1991; De Caritat et al., 1993) have further demonstrated that this empirical geothermometer has to be used carefully when applied to chlorites formed under conditions other than those in geothermal fields. De Caritat et al. (1993) have shown that chlorite composition is not only temperature dependent; coexisting minerals, bulk-rock composition, and primary mineralogy also interfere so that the results can often be over- or underestimated. However, according to Bevins et al. (1991) if this method is used to determine the temperature formation of chlorites in similar settings, the results can be satisfactory. We have applied Cathelineau's geothermometer to chlorites s.l. (i.e., type 2 phyllosilicates with Xc ranging from 0.80 to 1 ) to estimate the temperature of chlorite formation in the rocks of Hole 917A. The calculated temperatures range from $85^{\circ}$ to $167^{\circ} \mathrm{C}$ in the Upper Series, whereas they are in the interval $43^{\circ}-171^{\circ} \mathrm{C}$ for the Lower Series. These temperatures are broadly coherent with the stability domains of mafic phyllosilicates established in active geothermal wells. According to Kristmannsdóttir (1975, 1979), secondary mineral assemblages dominated by smectites are observed at temperatures lower than $180^{\circ} \mathrm{C}$, whereas chlorite s.s. becomes the dominant phase at $240^{\circ} \mathrm{C}$. At ODP Hole 504B, in the oceanic crust, saponite dominates in the low-temperature alteration zone where temperatures, based on oxygen isotopic data, are lower than $150^{\circ} \mathrm{C}$ (Honnorez et al., 1983; Alt et al., 1985; Shau and Peacor, 1992), whereas interstratified chlorite/smectites and chlorites occur at temperatures ranging from $200^{\circ}$ to $380^{\circ} \mathrm{C}$ (Alt et al., 1985). At Hole 917A, the estimated chlorite formation temperatures do not appear to vary with depth. Although the mainly smectitic clay mineralogy of the Middle Series may indicate lower temperatures, the homogeneity of chlorite temperatures above and below, and the zeolite mineralogy, suggest rather that the occurrence of smectites in the Middle Series is mainly controlled by bulk rock composition.

The lack of vertical zeolite zonation and the relative homogeneity of the estimated temperatures from both zeolites and interstratified chlorite/smectites strongly suggest that the alteration experienced by basalts from Hole 917A corresponds to an hydrothermal alteration where the temperature is more related to that of the circulating fluids than to burial depth. Therefore, the temperature at which very lowgrade metamorphic reactions took place in Hole 917A is the same in the three different series and was less than $170^{\circ} \mathrm{C}$.

Zeolite formation is only weakly pressure dependent. The secondary parageneses found at Hole 917A indicate low pressures $(<1.5$ kbars; Liou et al., 1987) and argue against an origin resulting from burial metamorphism.

\section{Fluid Compositions}

A striking feature of the metamorphic mineralogy of the basaltic rocks at Hole 917A is the sodic composition of the zeolites (chaba-

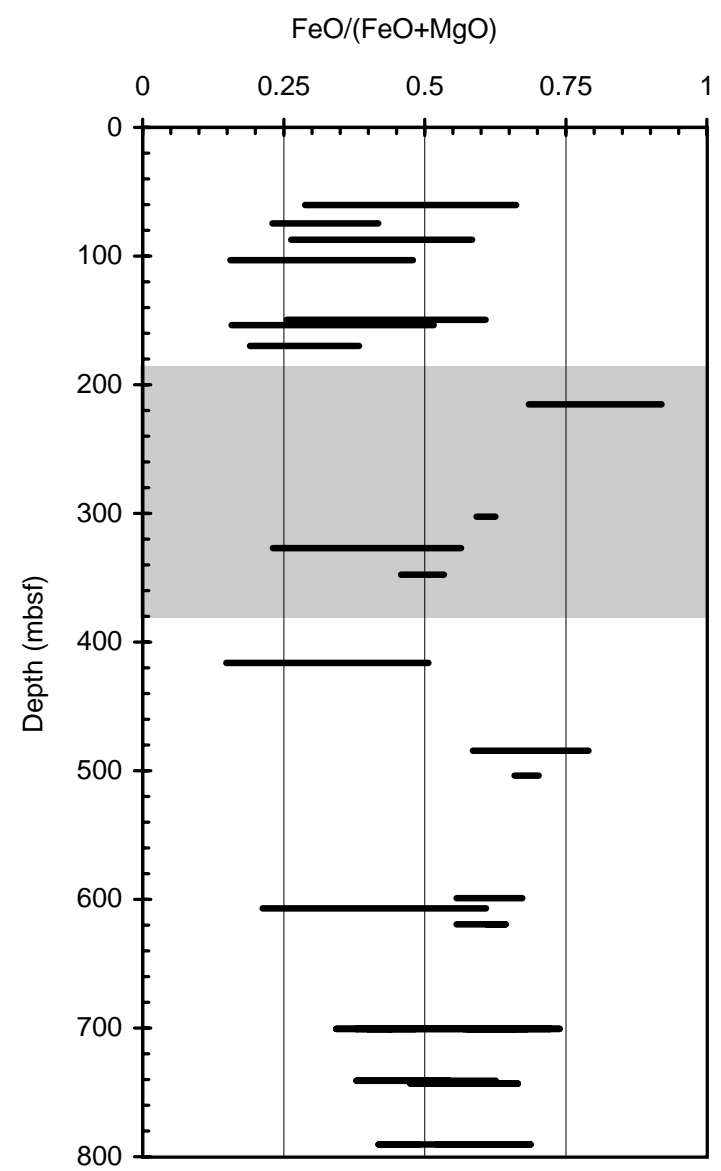

Figure 5. Plot of $\mathrm{FeO} /(\mathrm{FeO}+\mathrm{MgO})$ vs. depth for phyllosilicates from Hole 917A. The gray area represents the Middle Series. 

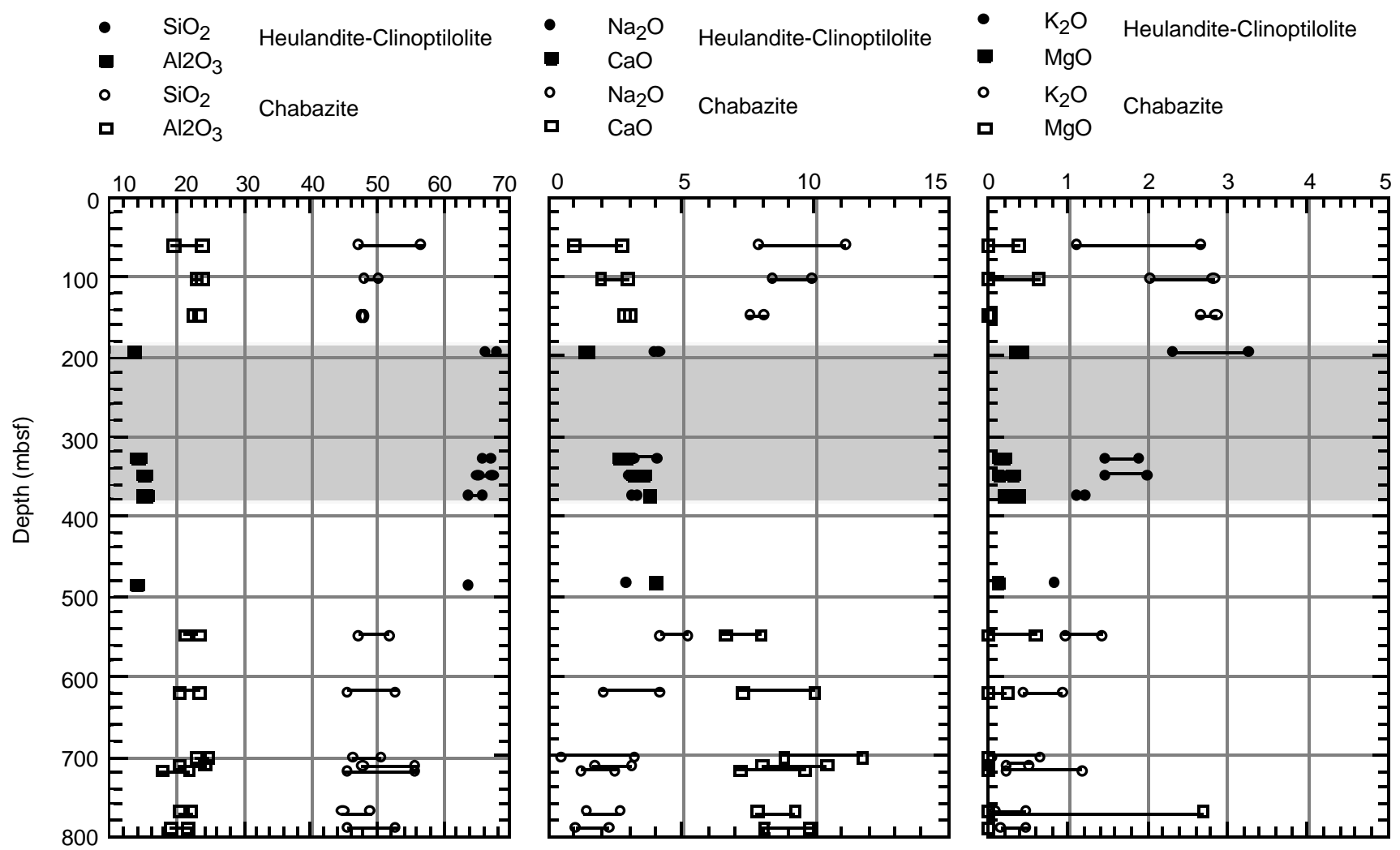

Figure 6. Plot of chemical compositions $\left(\mathrm{SiO}_{2}, \mathrm{Al}_{2} \mathrm{O}_{3}, \mathrm{CaO}, \mathrm{MgO}, \mathrm{Na}_{2} \mathrm{O}\right.$, and $\left.\mathrm{K}_{2} \mathrm{O}\right)$ of chabazite and heulandite-group zeolites vs. depth. The Middle Series is represented in gray.

zite, natrolite, analcite and heulandite-group). From the whole rock compositions $\left(\mathrm{Na}_{2} \mathrm{O}<2.5 \mathrm{wt} \%\right.$ for basaltic rocks in the Upper and Lower Series and $\mathrm{Na}_{2} \mathrm{O}<3.2 \mathrm{wt} \%$ in the more differentiated rocks of the Middle Series; Larsen, Saunders, Clift, et al., 1994) an external source for sodium is needed, and thus metamorphic reactions may have occurred in an open system. Chabazite, with a relatively calcic composition, and thomsonite (a calcic zeolite) are restricted to the Lower Series (Table 1). Moreover, the sodium content of chabazites and heulandite-group zeolites within a single series decreases regularly with depth, whereas the Ca content increases correlatively (Fig. $6)$. This general trend suggests that the external source for $\mathrm{Na}$ is the overlying seawater. The $\mathrm{K}$ content also decreases regularly with depth in the Middle and Lower Series while it increases with depth in the Upper Series. The Si and Al contents remain constant in each series, and the occurrence of a more silica-rich zeolite in the Middle Series (heulandite-group) correlates well with the more differentiated character of the volcanic rocks. Thus, the cationic composition of the two main zeolites in Hole 917A appears to be controlled mainly by the composition of the fluids percolating through the volcanic pile, whereas the influence of the host-rock chemistry is underlined by the variations in $\mathrm{Si}$ content. From the studies of metamorphosed basalts of the îles Kerguelen, differences in cationic composition between onland calcic chabazite (Nativel et al., 1994) and sodic chabazite in seafloor basalts (Sevigny et al., 1992) also demonstrate the influence of seawater during hydrothermal alteration.

Fe-rich saponites are usually related to non-oxidizing diagenesis, whereas Mg-saponites are characteristic of oxidizing domains. The more magnesian and less ferrous composition of the interstratified chlorite/smectites in the Upper Series, as compared with that of the Lower Series, appears to indicate that metamorphic reactions took place under more oxidizing conditions in the upper part of the volcanic pile, which also agrees with a decreasing influence of fresh oxygenated seawater with depth.

\section{CONCLUSIONS}

Zeolite and clay mineral assemblages present in the vesicles, veins, and groundmass of the different petrographic units recovered at Hole 917A are typical of very low-grade metamorphism in the zeolite facies, corresponding to temperatures less than $170^{\circ} \mathrm{C}$. This metamorphic event, which affected the whole volcanic pile, was clearly influenced by seawater, as demonstrated by the progressive increase of cationic Na toward the top in the chabazites and heulandite-group zeolites. As the entire volcanic sequence was erupted subaerially, this episode of hydrothermal alteration is clearly a late post-emplacement event that occurred in a marine environment, after the opening of the North Atlantic Ocean.

\section{ACKNOWLEDGMENTS}

This paper has benefited from detailed review and comment from L. Aguirre, R. Bevins, and Bob Wathen, as well as fruitful discussions with J-J. Cochemé concerning zeolites. C. Laverne and P. Pezard, through the results obtained at Hole 504B, inspired me to participate in an ODP leg. H. Cambray and D. Vandamme helped to give a "Marseille" touch to Leg 152. This study was supported by a CNRS-INSU grant (Geosciences marines 94GEO1/3.01).

\section{REFERENCES}

Aguirre, A., and Offler, R., 1985. Burial metamorphism in the Western Peruvian trough: its relation to Andean magmatism and tectonics. In Pitcher, W.S., Atherton, M.P., Cobbing E.J., and Beckinsale R.D. (Eds.), Magmatism at a Plate Edge: the Peruvian Andes: Glasgow (Blackie), 59-71.

Alietti, A., 1972. Polymorphism and crystal-chemistry of heulandites and clinoptilolites. Am. Mineral., 57:1448-1462. 
Alietti, A., Brigatti, M.F., and Poppi, L., 1977. Natural Ca-rich clinoptilolite (heulandites of group 3): new data and review. Neues Jahrb. Mineral. Monatsh, 11:493-501.

Alt, J.C., Laverne, C., and Muehlenbachs, K., 1985. Alteration of the upper oceanic crust: mineralogy and processes in Deep Sea Drilling Project Hole 504B, Leg 83. In Anderson, R.N., Honnorez, J., Becker, K., et al., Init. Repts. DSDP, 83: Washington (U.S. Govt. Printing Office), 217247.

Bettison, L.A., and Schiffman, P., 1988. Compositional and structural variations of phyllosilicates from the Point Sal ophiolite, California. Am. Mineral., 73:62-76.

Bettison-Varga, L., Mackinnon, I.D., and Schiffman, P., 1991. Integrated TEM-XRD and electron microprobe investigation of mixed-layer chlorite-smectite from the Point Sal ophiolite, California. J. Metamorph. Geol., 9:697-710.

Bevins, RE., Robinson, D., and Rowbotham, G., 1991. Compositional variations in mafic phyllosilicates from regional low-grade metabasites and application of the chlorite geothermometer. J. Metamorph. Geol., 9:711721.

Boles, J.R., 1972. Composition, optical properties, cell dimension, and thermal stability of some Heulandite group zeolites. Am. Mineral., 57:14631493

Cathelineau, M., 1988. Cation site occupancy in chlorites and illites as a function of temperature. Clay Mineral., 23:471-485.

Cathelineau, M., and Nieva, D., 1985. A chlorite solid solution geothermometer: the Loz Azufres (Mexico) geothermal system. Contrib. Mineral. Petrol., 91:235-244.

Chao, G.Y., 1980. Paranatrolite, a new zeolite from Mont St-Hilaire, Quebec. Can. Mineral., 18:85-88.

Cho, M., Maruyama, S., and Liou, J.G., 1987. An experimental investigation of heulandite-laumontite equilibrium at 1000 to 2000 bar $\mathrm{P}_{\text {fluid }}$. Contrib. Mineral. Petrol., 97:43-50.

Coombs, D.S., Ellis, A.J., Fyfe, W.S., and Taylor, A.M., 1959. The zeolite facies, with comments on the interpretation of hydrothermal syntheses. Geochim. Cosmochim. Acta, 17:53-107.

DeCaritat, P., Hutcheon, I., and Walshe, J.L., 1993. Chlorite geothermometry: a review. Clays Clay Miner., 41:219-239.

Evarts, R.C., and Schiffmann, P., 1983. Submarine hydrothermal metamorphism of the Del Puerto ophiolite, California. Am. J. Sci., 283:289-340.

Frey, M., deCapitani, C., and Liou, J.G., 1991. A new petrogenetic grid for low-grade metabasites. J. Metamorph. Geol., 9:497-509.

Gottardi, G., and Galli, E., 1985. Natural Zeolites: Berlin (Springer-Verlag).

Hawkins, D.B., 1974. Statistical analyses of the zeolites clinoptilolite and heulandite. Contrib. Mineral. Petrol., 45:27-36.

Honnorez, J., Laverne, C., Hubberten, H.-W., Emmermann, R., and Muehlenbachs, K., 1983. Alteration processes in Layer 2 basalts from Deep Sea Drilling Project Hole 504B, Costa Rica Rift. In Cann, J.R., Langseth, M.G., Honnorez, J., Von Herzen, R.P., White, S.M., et al., Init. Repts. DSDP, 69: Washington (U.S. Govt. Printing Office), 509-546.

Kristmannsdóttir, H., 1975. Clay minerals formed by hydrothermal alteration of basaltic rocks in Icelandic geothermal fields. Geol. Forening. Stockholm Forhandl., 97:289-292.

, 1979. Alteration of basaltic rocks by hydrothermal activity at 100-300 ${ }^{\circ}$ C. In Mortland, M., and Farmer, V. (Eds), Developments in Sedimentology, Amsterdam (Elsevier), 27:359-367.

Kristmannsdóttir, H., and Tómasson, J., 1978. Zeolite zones in geothermal areas in Iceland. In Sand, L.B., and Mumpton, F.A. (Eds.), Natural Zeolites: Occurrences, Properties, and Use: Oxford (Pergamon), 277-284.

Larsen, H.C., Saunders, A.D., Clift, P.D., et al., 1994. Proc. ODP, Init. Repts., 152: College Station, TX (Ocean Drilling Program).

LeHuray, A.P., and Johnson, E.S., 1989. Rb-Sr systematics of Site 642 volcanic rocks and alteration minerals. In Eldholm, O., Thiede, J., Taylor, E., et al., Proc. ODP, Sci. Results, 104: College Station, TX (Ocean Drilling Program), 437-448.

Liou, J.G., 1971. Stilbite-laumontite equilibrium. Contrib. Mineral. Petrol., 31: $171-177$.
Liou, J.G., deCapitani, C., and Frey, M., 1991. Zeolite equilibria in the system $\mathrm{CaAl}_{2} \mathrm{Si}_{2} \mathrm{O}_{8}-\mathrm{NaAlSi}_{3} \mathrm{O}_{8}-\mathrm{SiO}_{2}-\mathrm{H}_{2} \mathrm{O}$. N.Z. J. Geol. Geophys., 34:293-301.

Liou, J.G., Maruyama, S., and Cho, M., 1985. Phase equilibria and mineral parageneses of metabasites in low-grade metamorphism. Mineral. Mag., 49:321-333.

, 1987. Very low-grade metamorphism of volcanic and volcaniclastic rocks-mineral assemblages and mineral facies. In Frey, M. (Ed.), Very Low-Grade Metamorphism: New York (Blackie and Son), 59-113.

Malley, P., Juteau, T., and Blanco-Sanchez, J.A., 1983. Hydrothermal alteration of submarine basalts: from zeolitic to spilitic facies in the upper triassic pillow-lavas of Antalya, Turkey. Sci. Geol. Bull., 36:139-163.

Mason, B., and Sand, L.B., 1960. Clinoptilolite from Patagonia: the relationship between Clinoptilolite and Heulandite. Am. Mineral., 45:341-350.

Merlet, C., 1994. An accurate computer correction program for quantitative electron probe micro-analysis. Mikrochim. Acta, 114/115:363-376.

Morata, D., Aguirre, L., Puga, E., and Demant, A., 1995. Ceolitas en basaltos jurásicos de las Zonas Externas de las Cordilleras Béticas. Bol. Soc. Esp. Mineral., 18:127-142.

Mumpton, F.A., 1960. Clinoptilolite redefined. Am. Mineral., 45:351-369.

Nativel, P., Verdier, O., and Giret, A., 1994. Nature et diversité des zéolites de Kerguelen. Mem. Soc. Geol. Fr., 166:31-45.

Passaglia, E., 1970. The crystal chemistry of chabazites. Am. Mineral., 55:1278-1301.

Robert, C., 1988. Barian phillipsite and strontium chabazite from the Plateau des Coirons, Ardèche, France. Bull. Mineral., 111:671-677.

Robert, C., Goffé, B., and Saliot, P., 1988. Zeolitisation of a basaltic flow in a continental environment: an example of mass transfer under thermal control. Bull. Mineral., 111:207-223.

Robinson, D., 1987. Transition from diagenesis to metamorphism in extensional and collision settings. Geology, 15:866-869.

Robinson, D., and Bevins, R.E., 1989. Diastathermal (extensional) metamorphism at very low grades and possible high grade analogues. Earth Planet. Sci. Lett., 92:81-88.

Robinson, D., Bevins, R.E., and Rowbotham, G., 1993. The characterization of mafic phyllosilicates in low-grade metabasalts from eastern North Greenland. Am. Mineral., 78:377-390.

Sameshima, T., 1978. Zeolites in tuff beds of the Miocene Waitemata group, Auckland province, New Zealand. In Sand, L.B., and Mumpton, F.A. (Eds.), Natural Zeolites: Occurrence, Properties, and Use: Oxford (Pergamon Press), 309-317.

Schiffman, P., and Fridleifsson, G.O., 1991. The smectite-chlorite transition in drillhole $\mathrm{Nj}-15$, Nesjavellir geothermal field, Iceland: XRD, BSE and electron microprobe investigation. J. Metamorph. Geol., 9:679-696.

Schmidt, S.T., 1993. Regional and local patterns of low-grade metamorphism in the North Shore Volcanic Shore Group, Minnesota, USA. J. Metamorph. Geol., 11:401-414.

Sevigny, J.H., Whitechurch, H., Storey, M., and Salters, V.J.M., 1992. Zeolite-facies metamorphism of central Kerguelen Plateau basalts. In Wise, S.W., Jr., Schlich, R., et al., Proc. ODP, Sci. Results, 120: College Station, TX (Ocean Drilling Program), 63-69.

Shau, Y.H., and Peacor, D.R., 1992. Phyllosilicates in hydrothermally altered basalts from DSDP Hole 504B, Leg 83: a TEM and AEM study. Contrib. Mineral. Petrol., 112:119-133.

Verdier, O., Nativel, P., and Giret, A., 1988. Zéolitisation du plateau central des îles Kerguelen, Océan Indien. C.R. Acad. Sci. Ser. 2, 307:169-174.

Zen, E.-A., and Thompson, A.B., 1974. Low-grade regional metamorphism: mineral equilibrium relations. Annu. Rev. Earth Planet Sci., 2:179-212.

\footnotetext{
Date of initial receipt: 8 November 1995

Date of acceptance: 23 May 1996

Ms 152SR-231
} 